\title{
PRIMARY MENINGEAL BURKITT-TYPE LYMPHOMA PRESENTING AS THE FIRST CLINICAL MANIFESTATION OF ACQUIRED IMMUNODEFICIENCY SYNDROME
}

\author{
Pedro Luís Gobbato1, Arthur de Azambuja Pereira Filho, Gustavo de David², \\ Mário de Barros Faria², Felipe de David³, Pedro Bandeira Aleixo4, \\ Marinez Bizarro Barra ${ }^{5}$, Nelson Pires Ferreira ${ }^{6}$
}

\begin{abstract}
The purpose of this study is to report a rare case of primary meningeal high grade Burkitttype lymphoma presenting as the first clinical manifestation of acquired immunodeficiency syndrome. A 38-year-old Caucasian man, with a negative past medical history, sought treatment after experiencing global headache for five days. CT-Scan revealed a right front-temporo-parietal hyperdense subdural expansive mass. A craniotomy was performed and a hard white subdural was microsurgically dissected. Some hours after the surgery, the patient developed hemispheric cerebral edema and intracranial hypertension syn$\mathrm{d}$ rome. Decompressive craniotomy was performed and the patient had an excellent recovery. Screening blood tests diagnosed human immunodeficiency virus infection. Further investigation ruled out systemic diseases. Eleven days after the initial surgery, the patient developed an acute respiratory failure and sepsis, dieing on that day. Pathological studies diagnosed Burkitt-type lymphoma.
\end{abstract}

KEY WORDS: Burkitt-type lymphoma, meningeal neoplasm, acquired immunodeficiency syndrome.

\section{Linfoma de Burkitt primitivo da meninge como primeira manifestação clínica da síndrome da imunodeficiência adquirida}

\begin{abstract}
RESUMO - O objetivo desse estudo é relatar um caso de linfoma de Burkitt de alto grau primitivo da meninge, que se apresentou como primeira manifestação clínica da síndrome de imunodeficiência adquirida. Um homem branco, de 38 anos, previamente hígido, referia cefaléia holocraniana há cinco dias. A TC de crânio evidenciou coleção hiperdensa subdural na região fronto-temporo-parietal direita. Após craniotomia fronto-temporal direita, um tumor branco e rígido de localização subdural foi micro c i ru rgicamente ressecado. Algumas horas após, o paciente apresentou edema cerebral hemisférico e hipertensão intracraniana, tendo sido submetido à craniotomia descompressiva com excelente melhora clínica. Testes sorológicos evidenciaram infecção por vírus da imunodeficiência humana. Investigações complementares afastaram outras doenças sistêmicas. Onze dias após a primeira ciru rgia, o paciente apresentou insuficiência respiratória aguda e sepse, evoluindo para o óbito. Análise histopatológica evidenciou linfoma de Burkitt.
\end{abstract}

PALAVRAS-CHAVE: linfoma de Burkitt, tumor meningeal, síndrome da imunodeficiência adquirida.

Primarycentral nervous system (CNS) lymphoma is defined as non-Hodgkin's lymphoma arising within the CNS and confined to it at the time of diagnosis $^{1,2}$. It is a rare tumor, representing less than $2 \%$ of all primary brain tumors in some series ${ }^{3-6}$. Primary CNS lymphoma, including Burkitt-type lymphoma, usually presents either as a single or multicentric tumor, often located deeply in the cerebral hemi$\mathrm{sp} h$ e res with a predilection for periventricular brain tissue $^{3}$. A meningeal location has been estimated in around $7-10 \%$ of all cases, with a poor outcome not improved by aggressive systemic therapy ${ }^{7}$. The majority of these patients normally presents with seizures, headache, cranial nerves deficit, hemiparesis or arm

Hospital São José / Complexo Hospitalar Santa Casa de Porto Alegre (HSJ/CHSC), Porto Alegre RS, Brazil: ${ }^{1}$ Neurosurgeon at HSJCHSC; ${ }^{2}$ Medical - Residents in Neurosurgery at HSJ/CHSC; ${ }^{3}$ Medical Student - Universidade Federal de Santa Maria, RS (UFSM); ${ }^{4}$ Medical - Resident in Pathology at CHSC; ${ }^{5}$ Professor of Pathology at the Medical School, Fundação Faculdade Federal de Ciências

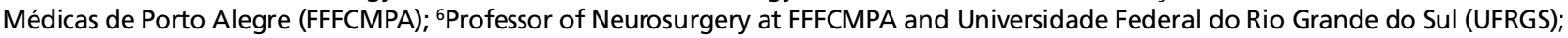
Chief of the Neurosurgery Service at HSJ-CHSC

Received 14 September 2005, received in final form 26 December 2005. Accepted 23 February 2006. 
paresthesia ${ }^{7}$. Primary CNS lymphoma has a much higher incidence in patients with established immune deficient status, and in acquired immunodeficiency synd rome (AIDS) patients it represents the most frequent brain tumor 8,9 . A high prevalence is also observed in renal and cardiac transplants, patients with IgA deficiency, or Wiskott-Aldrich syndrome ${ }^{10,11}$. A number of clinical re ports suggest an increasing incidence of this tumor over the past decades ${ }^{12-14}$, however there is no published data about it as the first clinical manifestation of AIDS.

The purpose of this study is to re port and discuss a rare case of primary meningeal high grade Burkitttype lymphoma, presenting as the first clinical manifestation of AIDS.

\section{CASE}

A 38-year-old Caucasian man, with a negative past medical history, sought treatment after experiencing global headache of moderate intensity for five days. There were no other complaints. The patient's neurological examination was intact. Computed tomography (CT-scan) revealed a right front-temporo-parietal hyperdense subdural expansive mass, with a $1 \mathrm{~cm}$ midline brain shift, suggesting an acute subdural hematoma (Fig1).

A right front-temporo-parietal craniotomy was performed. A hard white subdural mass with extension to frontal, temporal and parietal spaces was mirosurgically dissected (gross-total removal) (Fig 2). A few hours after the surgery, the patient developed right hemispheric cerebral edema and intracranial hypertension syndrome. Decompressive craniotomy was performed and the patient had an excellent recovery. Screening blood tests ( 2 samples) diagnosed human immunodeficiency virus (HIV) infection some days after the surgeries. This fact was not known neither by the patient nor by his family. Further complementary radiological and hematological investigation ruled out systemic diseases. Eleven days after the initial surg ery, the patient developed an acute respiratory failure and sepsis by a Pneumocistis carinni infection. The patient died on that day.

Pathological studies - At microscopy the biopsy was characterized by a diffuse monotonous infiltrate of medium sized cells, with a slight molding pattern. The distinct starry-sky pattern caused by interspersed tingible-body macrophages was present. The cells showed round nuclei, with coarse chromatin and basophilic nucleoli, with a notable rim of basophilic cytoplasm. Karyorrhectic debris and mitotic figures were frequent. Immunohistochemically, the tumor expressed positivity for B cell markers CD20 and CD79a. CD10 and Bcl-6 were also positive. Theproliferative index measured by the $\mathrm{Ki}-67$ was very high bearing $100 \%$. The negativity to $\mathrm{Bcl}-2$ also helped in the differential diagnosis with diffuse large B cell lymphoma. These features are compatible with high grade Burkitt-type lymphoma (Fig 3).

\section{DISCUSSION}

CNS lymphoma is a rare tumor, representing 1 - $2 \%$ of all primary brain tumors ${ }^{3-6,15}$. The majority of CNS lymphomas consist of secondary involvement of the brain, spinal cord, or covering membranes by nodal or extranodal (rather than CNS) lymphomas ${ }^{16}$. Primary CNS lymphoma is by definition an extranodal lymphoma arising in the central nervous system in the absence of systemic disease ${ }^{3}$. These tumors are primarily the non-Hodgkin type, and are high grade and of B-cell lineage, with large cell morphological characteristics, although nearly all other types of malignant lymphoma of the CNS are on record" ${ }^{\text {n. }}$.

Primary CNS lymphoma has a much higher incidence in patients with established immune deficient status, especially in AIDS patients ${ }^{3}$. In its early stages, human immunodeficiency virus infection has no symptoms or causes only a flu-like illness with many of the following symptoms: fever, sore throat, rash, nausea and vomiting, diarrhea, fatigue, swollen lymph nodes, muscle aches, headaches and joint pain. When the number of CD4 cells drops significantly, the patient develops AIDS and opportunistic infections may overcome. Some of the germs that can cause these include Candida fungus, cryptococcosis, cytomegalovirus, herpes simplex virus, Mycobacterium

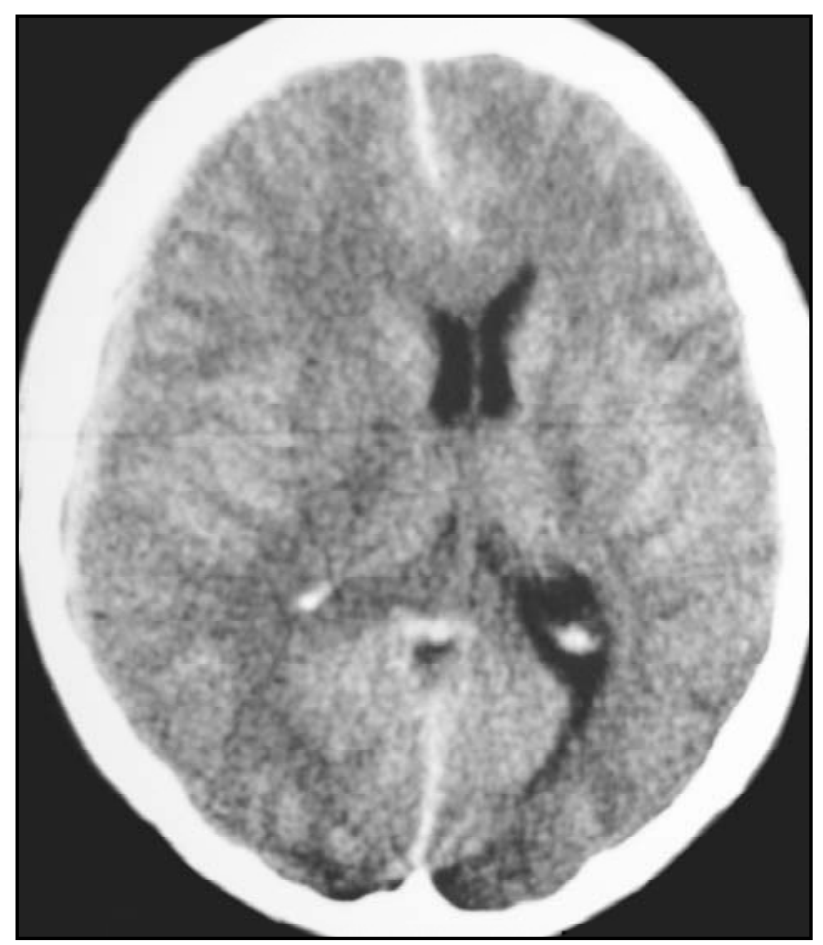

Fig 1. CT-scan showing the right front-temporo-parietal hyperdense subdural expansive mass, with a $1 \mathrm{~cm}$ midline brain shift, suggesting an acute subdural hematoma. 


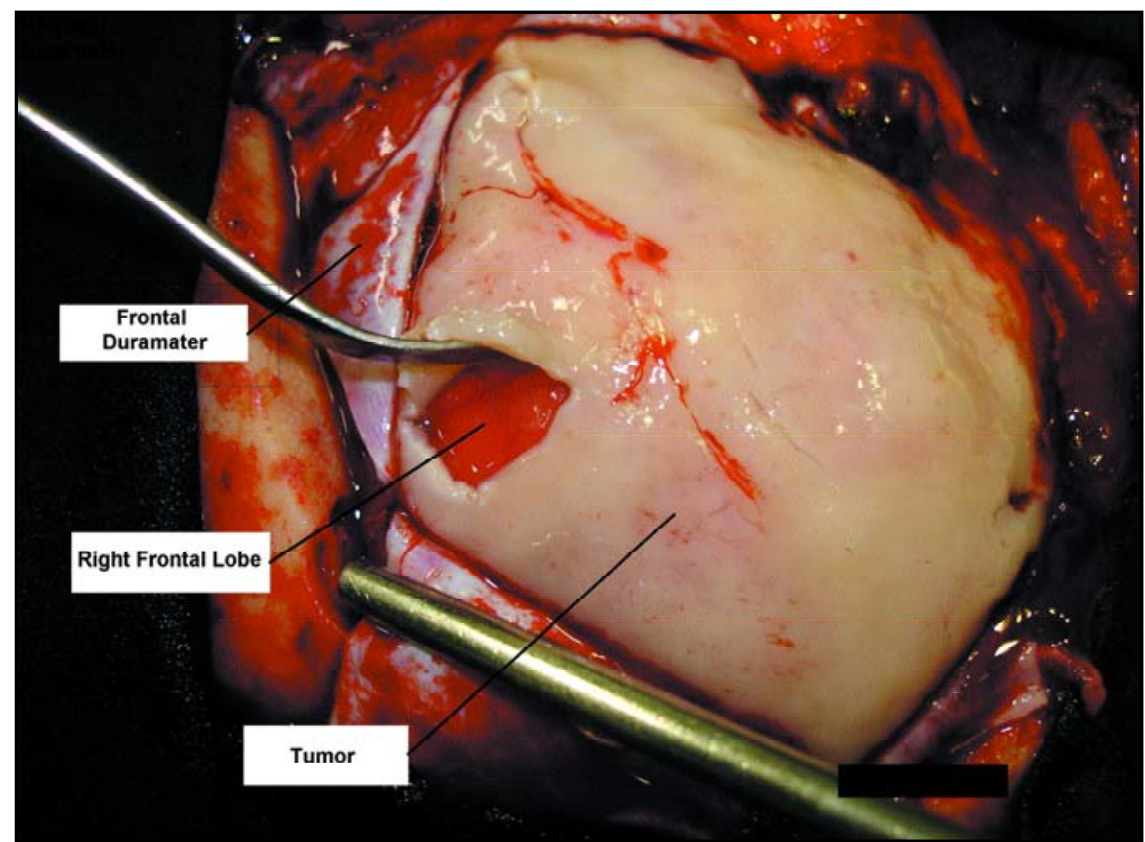

Fig 2. Transoperative photography showing the meningeal Burkitt-type lymphoma with subdural extension.

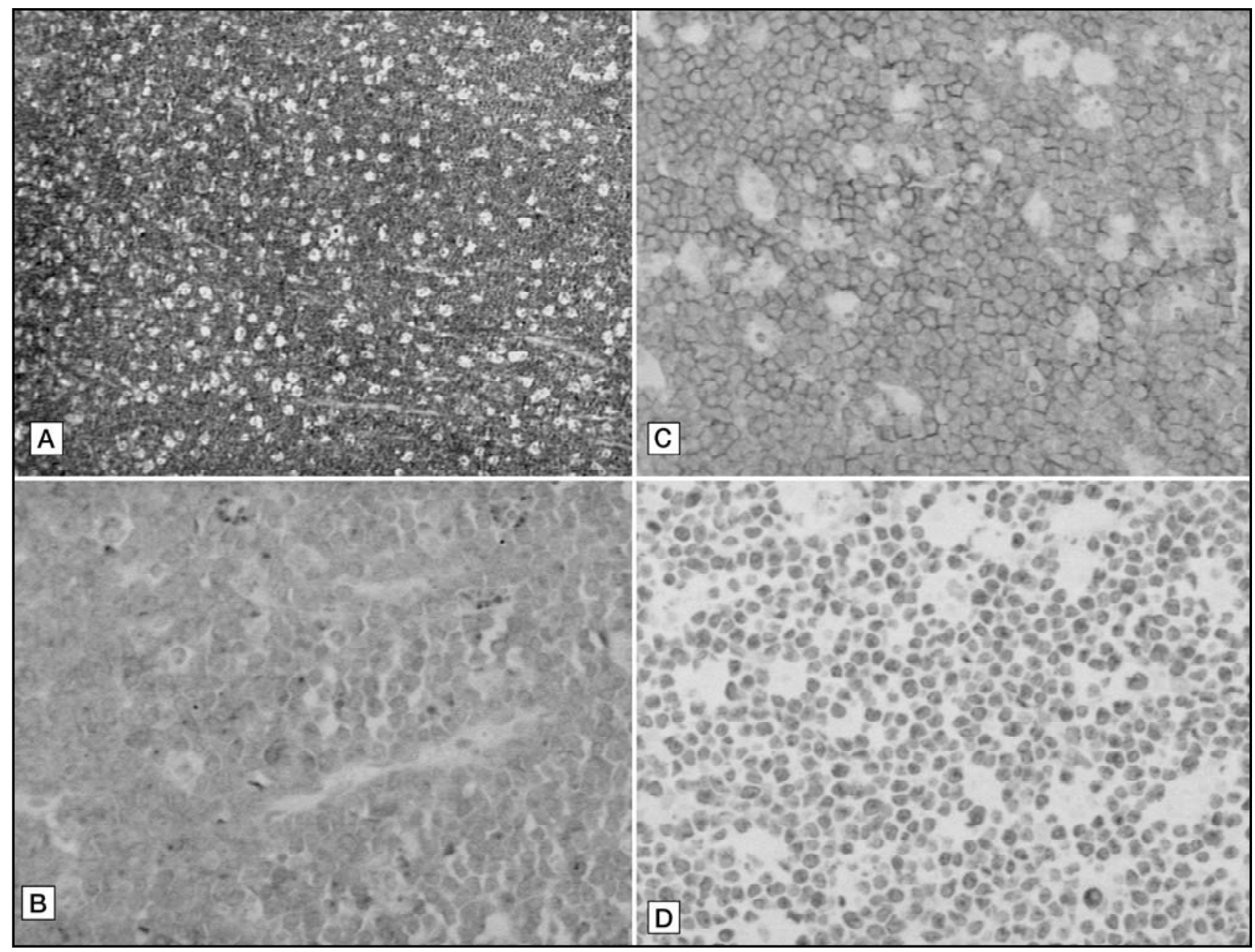

Fig 3. A) Histological examination, H \& E; B) CD10 (56C6): positive (neoplasic B-cells); C) CD 20 (L26): positive (neoplasic B-cells); d) Ki 67 (MIB 1) immunostaining proliferative index. 
avium complex and Pneumocystis carinii. A tumor may also develop, including cervical cancer, Kaposi's sarcoma and certain types of non-Hodgkin's lymphoma, as brain lymphoma ${ }^{17}$. Primary meningeal Burkitt-type lymphoma as the first manifestation of AIDS has not been reported previously.

The incidence of primary central nervous system lymphomas among immunocompetent and immunocompromised patients has been on the rise in the past three decades ${ }^{3,18,19}$. This rise can be partially attributed to the prolonged survival of AIDS patients and the extensive use of immunosuppressive therapy in organ transplantation and autoimmune disease $^{3,6}$.

Most authors have found that primary CNS lymphoma is a disease of late middle age $\mathrm{e}^{3,20,21}$ but some series describe a diffe rent age distribution, with the majority of patients being in the seventh, eighth or even in the ninth decades of life ${ }^{12}$. In the present case, the patient was in the third decade of life, which is an atypical age for this disease according to the literature.

A preoperative diagnosis of primary CNS lymphoma can be made with a high degree of cert a inty if the lesion is hyperdense on CT-scan, is invasive to the surrounding parenchyma, shows homogeneous enhancement, and has broad contact with ependyma and/or leptomeninges ${ }^{16,22}$. In a large number of cases, Lee et al. ${ }^{22}$ evaluated CT-scan findings in some brain lymphomas and have correlated these findings with the tumors' pathological features. These authors have clearly discussed that homogeneous enhancement of primary CNS lymphoma on CT scanning is a common phenomenon, but that peripheral enhancement may be rarely seen, especially in AIDS related lymphomas. They found central necrosis in the highgrade lymphomas with peripheral enhancement; none of those cases were the Burkitt type.

In the present case, it was observed an abnorm a I radiological imaging in contrast with those usual findings described above: the CT-scan revealed a fronttemporo-parietal hyperdense subdural expansive mass, which suggested an acute subdural hematoma, needing urgent neurosurgical intervention.

Dubuisson et al. ${ }^{12}$ reported a series where the vast majority of primary CNS lymphomas were supratentorial; approximately $60 \%$ were deeply located; $25 \%$ of patients presented multiple lesions. A meningeal location of primitive CNS has been estimated in around $7-10 \%$ of all cases, with a poor outcome not improved by aggressive systemic therapy. In the present case, a poor outcome was unfortunately achieved, even with aggressive surgical management for the primary meningeal CNS lymphoma.

Several questions remain regarding the optimal management of patients with primary CNS lymphoma ${ }^{21,23,24}$. Surgery traditionally plays little or no role in the treatment of primary central nervous system lymphoma due to its infiltrative behavior and often multicentric appearance. Bataille et al..$^{25} \mathrm{pre}$ sented a re trospective multicentric-based analysis of 248 cases, $51 \%$ of them with surgical resection. They concluded that partial surgical resection was an unfavorable prognostic factor. However, no specific information was given about extent of resection and selection criteria. In this respect most reports give information regarding survival regardless of the multiplicity of the lesion and the extent of resection ${ }^{26,27}$. The results of surgical treatment are often based on a high percentage of multicentric lesions or partial resection $^{28}$. This makes it difficult to determine the impact of surgery on survival. Although stereotactic biopsy appears to be indicated in multicentric cases, the re may be a subset of patients with well circ u mscribed and surgically accessible lesions that could benefit from surgical resection ${ }^{3}$.

Primary CNS lymphoma is clearly a both chemosensitive and radiosensitive tumor. The current therapeutic recommendations place chemotherapy as the first line of treatment ${ }^{29,30}$ : chemotherapy alone is used for patients older than 60 years, radiotherapy being reserved to patients with residual tumor after chemotherapy. The combined treatment of chemotherapy followed by radiotherapy is apllied to the patients younger than 60 years. Some studies have demonstrated that methotrexate remains the most important single agent effective in primary CNS lymphoma, because of its good blood brain barrier penetration and its tumoricidic activity ${ }^{20}$. In the present case, it was not possible to offer complementary treatment besides aggressive surg e ry, because of the poor outcome of our patient.

In conclusion, although a threefold increase in the incidence of primary CNS lymphomas has been reported recently, primary meningeal high grade Burkitt-type lymphoma is still a very rare tumor. The peculiarities of this case are the lesion's topography, its radiological characteristic and the fact that the primarymeningeal high grade Burkitt-type lymphoma presented as the first clinical manifestation of AIDS. 


\section{REFERENCES}

1. Jahnke K, Thiel E, Schilling A, et al. Low grade primary central nervous system lymphoma in immunocompetent patients. Br J Haematol 2005; 128:616-624.

2. Plasmwilm L, Herrlinger U, Korfel A, et al. Primary central nervous system (CNS) lymphoma in immunocompetent patients. Ann Hematol 2002;81:415-423.

3. Bellinzona M, Roser F, Ostertag H, Gaab RM, Saini M. Surgical removal of primary central nervous system lymphomas (PCNSL) presenting as space occupying lesions: a series of 33 cases. EJSO 2005; 31: 100-105.

4. Abrey LE, DeAngelis LM, Yahalom J. Long-term survival in primary CNS lymphoma. J Clin Oncol 1998;16:859-863.

5. Mead GM, Bleehen NM, Gregor A, et al. A medical researh council randomized trial in patients with primary cerebral non-Hodgkin lymphoma: cerebral radiotherapy with and without cyclophosphamide, doxorubicin, vincristine, and predinisone chemotherapy. Cancer 2000; 89:1359-1370.

6. Camilleri-Brot S, Martin A, Moreau A, et al. Primary central nervous system lymphomas in 72 immunocompetent patients: pathologic findings and clinical correlations Groupe Ouest Est d etude des Leucenies et Autres Maladies du Sang (GOELAMS). Am J Clin Pathol 1998;110: 607-612.

7. Lachance DH, O`Neill BP, Macdonald DR. Primary leptomeningeal lymphoma: report of 9 cases, diagnosis with immunocytochemical analysis, and review of the literature. Neurology 1991;41:95-100.

8. Ciacci JD, Tellez C, VonRoenn J, Levy RM. Lymphoma of the central nervous system in AIDS. Semin Neurol 1999;19:213-221.

9. Schabet M. Epidemiology of primary CNS lymphoma. J Neurooncol 1999;43:199-201.

10. Boder E. Ataxia-telangiectasia: some historic, clinical and pathologic observations. Birth Defects Orig Artic Ser 1975;11:255-270.

11. Burkhard D, Schipper HI, Kaboth U, Felgenhauer K. IgA producing primary intracerebral lymphoma. J Neurol Neurosurg Psychiatry 1992;55:623-625.

12. Dubuisson A, Kaschten B, Lénelle J, et al. Primary central nervous system lymphoma: report of 32 cases and review of the literature. Clin Neurol Neurosurg 2004;107:55-63.

13. Corn BW, Marcus SM, Topham A, Hauck W, Curran WJ. Will primary central nervous system lymphoma be the most frequent brain tumor diagnosed in the year 2000? Cancer 1997;79:2409-2413.

14. Eby NL, Grufferman S, Flannelly CM, Schold SC, Vogel FS, Burger PC Increasing evidence of primary brain lymphoma in the US. Cancer 1988;62:2461-2465.
15. Menniti A, Moschettoni L, Liccardo G, Lunardi P. Low-grade primary meningeal lymphoma: case report and review of the literature. Neurosurg Rev 2005;28:229-233.

16. Monabati A, Rakei M, Kumar P, Taghipoor M, Rahimi A. Primary Burkkit lymphoma of the brain in an immunocompetent patient. J Neurosurg 2002;96:1127-1129.

17. Bennett JC, Plum F. Cecil Tratado de Medicina Interna, $20^{\mathrm{a}}$ Ed. Rio de Janeiro: Editora Guanabara Koogan S.A., 1997:2027-2088.

18. Bacellar H, Munoz A, Miller EM, et al. Temporal trends in the incidence of HIV-1-related neurologic diseases: multicenter AIDS cohort study, 1985-1992. Neurology 1994;44:1892-1900.

19. Hao D, DiFrancesco LM, Brasher PM, et al. Is primary CNS lymphoma really becoming more common? A population-based study of incidence, clinicopathological features and outcomes in Alberta from 1975 to 1996. Ann Oncol 1999;10:65-70.

20. Batchelor T, Carson K, O`neill A, et al. Treatment of primary CNS lymphoma with methotrexate and deferred radiotherapy: a report of NABTT 96-07. J Clin Oncol 2003;21:1044-1049.

21. Socié G, Piprot-Chauffat C, Schlienger M, et al. Primary lymphoma of the central nervous system. Cancer 1990;65:322-326.

22. Lee YY, Bruner JM, Van Tassel P, et al. Primary central nervous system lymphoma: CT and pathologic correlation. AJR 1986;147:747-752.

23. Bataille B. Traitment des lymphomas cérébraux primitives. Principes généraux et resultants. Neurochirurgie 1997;43:372-375.

24. Shibamoto Y, Tsutsui K, Dodo Y, Yamabe H, Shima N, Abe M. Improved survival rate in primary intracranial lymphoma treated by high-dose radiation and systemic vincristine-doxorubicin-cyclophosphamideprednisolone chemotherapy. Cancer 1991;65:1907-1912.

25. Bataille B, Delwail V, Menet E, et al. Primary intracerebral malignant lymphoma: report of 248 cases. J Neurosurg 2000;92:261-266.

26. Henry JM, Heffner Jr RR, Dillard SH, Earle KM, Davis RL. Primary malignant lymphomas of the central nervous system. Cancer 1974;34:1293-1302.

27. O`Neill BP, Illig JJ. Primary central nervous system lymphoma. Mayo Clin Proc 1989; 64:1005- 1020

28. Hayakawa T, Takakura $\mathrm{K}$, Abe $\mathrm{H}$, et al. Primary central nervous system lymphoma in Japan: a retrospective, cooperative study by CNSLymphoma Study Group in Japan. J Neurooncol 1994;19:197-215.

29. De Angelis LM. Primary central nervous system lymphoma. Curr Opin Neurol 1999;12:687-691.

30. Delwail V, Bataille B. La chimiothérapie des lymphomas cérébraux primitives. Neurochirurgie 1997;43:380-384. 